\title{
ADVERSE SELECTION AND MORAL HAZARD IN FORUM SHOPPING: \\ CONFLICTS LAW AS SPONTANEOUS ORDER \\ NitA GHEI ${ }^{1}$ AND FRANCESCO PARISI ${ }^{2}$
}

\begin{abstract}
The development of ... rules will ... involve a continuous interaction between the rules of law and expectations: while new rules will be laid down to protect existing expectations, every new rule will also tend to create new expectation. As some of the prevailing expectations will always conflict with each other, the judge will constantly have to decide which is to be treated as legitimate and in doing so will provide the basis for new expectations. ...[T]he judge will never be able to foresee all the consequences of the rule he lays down, and will often fail in his endeavor to reduce the sources of conflicts of expectations .... [I]t is only by their effects on [the] order of actions, effects that will be discovered only by trial and error, that the adequacy or inadequacy of the rules can be judged. ${ }^{3}$
\end{abstract}

\section{INTRODUCTION}

\section{Hypothetical Number One}

A pair of men engage in a murder spree, with victims scattered over three states. Once they are captured, where are they to be charged and tried? In the United States, they could be tried for murder in any one or all of the three states. In addition, they could face prosecution in federal court on related charges. Suppose further that the states had different penalties for murder, with a capital sentence available in only one of the states. The prosecutors decide to charge the men with the crimes in the death penalty state. ${ }^{4}$

\footnotetext{
${ }^{1}$ Clerk to the Hon. John C. Eldridge, Court of Appeals of Maryland. J.D., George Mason University School of Law, Ph.D. (Economics), University of Maryland, College Park, B.A. (Economics), Delhi University.

${ }^{2}$ Professor of Law \& Director, Law and Economics Program, George Mason University School of Law.

${ }^{3}$ Friedrich A. HAYeK, LAW, LegisLATION AND Liberty: RULES AND ORDER 102 (1973).

${ }^{4}$ This hypothetical is loosely based on the widely publicized "Beltway Snipers" case. John Allen Muhammad and John Lee Malvo are alleged to have committed murders in Virginia, Maryland and the District of Columbia. They are being tried in Virginia, where the death penalty is a possibility. At the time the two were charged, Maryland had a moratoriam on the death penalty. The choice of penalties was one of reasons why the prosecutors chose Virginia as the forum. See Susan Schmidt and Josh White, Sniper Suspects Handed to Va. for Trials, WASH. POST, Nov. 8, 2002 , at A1.
} 


\section{Hypothetical Number Two}

A man commits a murder in an American state, and then flees overseas to another country known to prohibit extradition of its citizens to the United States. Even though this man was born in the United States, he claims citizenship of the foreign country based on the fact that his father was a citizen of the foreign country at the time of his birth. That country's Supreme Court agrees, and holds that the policy of not extraditing citizens applies to the man. Further suppose that this country has a policy of pursuing a domestic prosecution in such cases. However, the maximum sentence it imposes is lighter than the minimum the man would have received in the United States if he had been convicted. ${ }^{5}$

In both the cases, the very fact that the more than one state can legitimately exercise jurisdiction over the parties gives rise to the possibility that the outcome depends on the choice of forum. In the first case, the choice of forum rests with the prosecution; in the second with the defendant. The prosecution will seek a forum with the highest penalty; the defendant will try to get a forum with the lightest sentence. That, after all, is simply rational behavior. ${ }^{6}$ But, while prosecutors often make such decisions with little public acknowledgment or outcry, a defendant exercising a similar choice could face vociferous condemnation. ${ }^{7}$

\footnotetext{
${ }^{5}$ This hypothetical draws on the case of Samuel Sheinbein, who was suspected of committing a murder in Maryland. He fled to Israel before a warrant was issued for his arrest. He subsequently pleaded guilty to the murder and is serving out his sentence in an Israeli prison. See Att'y Griev. Com'm v. Sheinbein 372 Md 224, 230-34 (2002) (disbarring Samuel Sheibein's father, a member of the Maryland Bar, for his role in assisting Samuel's flight to Israel).

${ }^{6}$ Rationality in this sense draws from the economics literature, and refers to the notion that each party will attempt to maximize his own utility. For a prosecutor, other things being equal, the best result would be getting the maximum penalty. For a defendant, if conviction is inevitable, and other things being equal, the lowest sentence maximizes utility, in that it is the least bad outcome available.

${ }^{7}$ The dissent in Att'y Griev. Com'm v. Sheibein, 372 Md 224, 269 supra, makes this point, saying, Indeed, when more than one sovereign has jurisdiction to prosecute a person for homicide, it appears to be entirely appropriate for those on the prosecution side to send the alleged perpetrator to the
} 
The notion that the choice of forum could, at an extreme, literally be a matter of life and death for the defendant, as is the case in these hypotheticals, is intuitively troubling. But, in a world with overlapping jurisdictions, multiple legal regimes and transactions that span these jurisdictions, a legal dispute, including criminal cases such as these, might often be pursued in more than one jurisdiction. Inevitably, in some, if not many cases, the outcome could depend on the choice of forum, which in turn, raises the issue of who controls the choice of forum.

The availability of alternative forums has troubled conflicts scholars, on the grounds that this "forum shopping" was inefficient ${ }^{8}$ or unjust. ${ }^{9}$ Among the suggestions made to rectify this allegedly chaotic situation is national conflicts legislation; ${ }^{10}$ a new Restatement; ${ }^{11}$ and less radical modifications using efficiency as a yardstick. ${ }^{12}$ One scholar has suggested that there is no significant problem as conflicts law is, at best, marginally relevant to the final outcome of litigation. $^{13}$

sovereign likely to impose the most severe punishment. *** According to the majority opinion, however, it is not appropriate for those on the defense side to send the alleged perpetrator to the sovereign likely to impose a less severe punishment. If prosecutors are free to forum-shop for a jurisdiction with more severe penalties, or a broader capital punishment statute, when choosing where to prosecute the accused, the defense should not be punished for sending the accused to a jurisdiction with less severe maximum penalties. (Eldridge J., dissenting) (footnote omitted).

${ }^{8}$ See e.g., Erin A. O'Hara and Larry E. Ribstein, From Politics to Efficiency in Choice of Law, 67 U. CHI. L. REV. 1151 (2000); Kimberly A. Moore, Forum Shopping in Patent Cases, 79 N.C.L. REV. 889 (2001); Kimberly A. Moore and Francesco Parisi, Rethinking Forum Shopping in Cyberspace, available at www.ssrn.com.

${ }^{9}$ See e.g., Ralph U. Whitten, Curing The Deficiencies of the Conflicts Revolution: A Proposal for National Legislation on Choice of Law, Jurisdiction, and Judgments, 37 WILLAMETTE L. REV. 259 (2001).

${ }^{10}$ See Symeon C. Symeonides, The Need For a Third Conflicts Restatement (And a Proposal for Torts Conflicts), 75 IND. L.J. 437 (2000).

${ }^{11}$ See O'Hara and Ribstein, supra note 8.

${ }^{12}$ See O'Hara and Ribstein supra note 8.

${ }^{13}$ See Stewart E. Sterk, The Marginal Relevance of Choice of Law Theory, 142 U. PA. L. REV. 949 (1994). 
This article argues that fears about the seeming chaos of conflicts law are overblown. Conflicts law has emerged largely from the common law, and is an example of what Friedrich Hayek termed "spontaneous order."14 The superficial confusion observed in conflicts law does not mean that there are no underlying rules. In fact, conflicts law is an example of Hayek's nomos, and it has evolved so as to maintain a spontaneous order that sustains liberty, cosmos, in Hayek's terminology. ${ }^{15}$ The paper examines the rules that have evolved over time and argues that these rules work to largely correct the problems of adverse selection ${ }^{16}$ and moral hazard ${ }^{17}$ inherent in a world where parties have the choice of alternative forums, particularly in the United States, with the additional bounds imposed by constitutional restrictions on personal jurisdiction. ${ }^{18}$ Thus, while a perfect result, where the same circumstances always lead to the same outcome, is not possible every time, conflicts law has evolved so as to fulfill legitimate

\footnotetext{
${ }^{14}$ See Hayek supra note 3.

${ }^{15}$ See Hayek supra note 3 at 35 - 54, 94 - 123.

${ }^{16}$ Adverse selection refers to a situation where parties have asymmetric information. The classic examples are the market for used cars and the credit market. In the used car market, there are good cars and bad cars; only the seller knows the quality of his own car. The buyer does not have this information. Thus, the buyer will be willing to pay a maximum price that is equal to the expected value of the car, some average of the price of good and bad cars. This is lower than the value of a good car, and no seller with a good car will be willing to sell at this price. The good cars get driven out of the market, leaving only the "lemons" in the market. See George Akerloff, The Market for Lemons, 84 Q. J. ECON. 588 (1970). Similarly, only the borrower knows his credit worthiness of the borrower accurately; the lender can only reach imperfect estimates, as the borrower has private information about his personal characteristics. However, only very risky borrowers would be willing to borrow at very high interest rates. This reduces the average expected return to the bank. Thus, the profit-maximizing bank will not increase the interest rate above some level where only very high risk creditors would be in the market. The result is some degree of credit rationing in equilibrium in the market. See Joesph E. Stiglitz and Andrew Weiss, Credit Rationing in Markets With Imperfect Information, 71 AM. ECON. REV. 393 (1981).

${ }^{17}$ Moral hazard is a concept that is best explained in terms of insurance. If a person has insurance, such that a third party is responsible for covering all losses, that person's incentive to take precautions to prevent harm is reduced. This is moral hazard. See, e.g., Steven Shavell, On Moral Hazard and Insurance, 93 Q.J. Econ. 541 (1979).

${ }^{18}$ We argue that holds even for the much reviled Restatement (Second) of Conflicts.
} 
expectations most of the time. While the present body of conflicts law is not perfect, like democracy, it is better than any of the suggested alternatives. ${ }^{19}$

Part I explores the various approaches to conflicts of law, and how they give rise to the possibility of forum shopping. Part II examines the adverse selection and moral hazard problems inherent in forum shopping. Part III examines how conflicts law has evolved to solve such problems in the case of contracts, torts and real property. This supports the conclusion that conflicts law is part of the spontaneous order from which the law of liberty, in the Hayekian sense, evolves. Part IV concludes by distinguishing between legitimate forum selection and illegitimate forum shopping.

\section{APPROACHES TO CONFLICT OF LAWS}

Conflict of laws rules are rules of the domestic jurisdiction that are used to deal with disputes that are involve the interests of more than one jurisdiction. ${ }^{20}$ The dispute can involve the interests of more than one state, within the United States, or more than one nation. The approaches discussed here apply in both the interstate and international disputes; there is no reason to treat them differently and we do not distinguish between intra-state and international applications.

\footnotetext{
${ }^{19}$ The following quotation is attributed to Winston Churchill, as part of a speech he made in the House of Commons in 1947:

"Many forms of Government have been tried, and will be tried in this world of sin and woe. No one pretends that democracy is perfect or all-wise. Indeed, it has been said that democracy is the worst form of Government except all those others that have been tried from time to time."

${ }^{20}$ See Francesco Parisi and Erin O'Hara, Conflict of Laws, PALGRAVE Dictionary OF LAW AND EconOmics 387, 387.
} 
Modern conflicts of laws approaches address three main issues: adjudicatory jurisdiction, substantive competence and choice of governing law; and recognition of judgments. ${ }^{21}$ Traditionally, the goals of conflicts systems were held to be uniformity, predictability and avoidance of forum shopping. ${ }^{22}$ However, these goals were de-emphasized in Brainerd Currie's interest analysis approach, ${ }^{23}$ with his focus on other values, including policy goals of the state. Nonetheless, uniformity and predictability remain important; the idea that the choice of forum can result in different outcomes of identical cases remains intuitively troubling.

Thus, the extent to which a conflicts system achieves the goals of uniform, predictable outcomes is a yardstick for measuring the "success" of that system. An ideal conflicts regime would satisfy what we term the "mirror-image" test: the same set of facts should result in the application of the same substantive law, regardless of the forum in which suit is bought. Such a system would eliminate the incentive to forum shop.

Over time, three major approaches to conflicts of laws have developed that seek to achieve some sort of balance between the three goals of uniformity, predictability, and avoidance of forum shopping. The first is lex fori, or a unilateral approach, where the law of the forum is always applied. This is the simplest approach and appealing for this reason, but, as is discussed below, is rife with problems in its application. The second is a multilateral approach, where the court attempts to balance the interests of the connected jurisdictions. Standards based regimes, such as interest analysis and the multifactor-tests of Restatement (Second), fall within this category. Rules-based regimes, such as those in civil law countries and the Restatement (First),

\footnotetext{
${ }^{21}$ Parisi and O'Hara supra note 20.

${ }^{22}$ See Whitten supra note 9; Parisi and O'Hara supra note 20; O'Hara and Ribstein supra note 8; and Moore supra note 2. See generally, Lea Brilmayer, Conflicts of Laws ( $4^{\text {th }}$ ed. 1995).

${ }^{23}$ See Brainerd Currie, Survival of Actions: Adjudication Versus Automation in the Conflict of Laws, in SELECTED ESSAYS IN THE CONFLICT OF LAWS, 128, 168 (1963).
} 
also are multilateral in approach. The third is a substantive approach, which effectively tries to apply the best law to the same fact pattern, regardless of whether the dispute in between intrastate or interstate parties. ${ }^{24}$ Leflar's "better rule of law" approach falls within this category.

\section{A. Unilateral approach}

One straightforward solution to conflicts law would be to apply forum law always. ${ }^{25}$ This has the advantages of simplicity, clarity and predictability. This approach has advantages for local actors, including the state officials. The costs of applying local law are lower for the local justice system; thus there is an argument of judicial economy that supports this approach. Further, deciding a case according to local law creates valuable precedent, which is a public good and results in an increase in social welfare. ${ }^{26}$ Predictability about the use of forum law reduces a source of uncertainty for parties structuring transactions. As long as parties can exit the system, the lex fori approach forces a state to internalize the external costs of bad laws, promoting competition among jurisdictions to improve substantive law. ${ }^{27}$

Or so it should be, in theory. In reality, because there is both common law and legislation, the certainty of knowing that forum law will always apply could exacerbate the problem by encouraging forum shopping. This certainty gives interest groups an incentive to

\footnotetext{
${ }^{24}$ See Parisi and O'Hara, supra note 20. See also Stanley E. Cox, Substantive, Multilateral and Unilateral Choice of Law Approaches, 37 WiLlametTE L. REV. 171, 173 (2001).

${ }^{25}$ See Parisi and O'Hara, supra note 20 at 390.

${ }^{26}$ A public good is characterized by two features with respect to its consumption: non-excludabability and nonrivalry. That is, once the good is produced, it is impossible to exclude anyone from deriving benefit from it, and this use by one does not diminish the amount available for anyone else. A standard example of a public good is that of the reputation of a university. All students derive the benefit of an improvement in this reputation, without any rivalry in this "consumption" of the benefit. Similarly, the valuable legal precedent is available for use to all parties, without reducing access to the precedent to anyone. See generally, DENNIS C. MUELLER, PUBLIC CHOICE II.

${ }^{27}$ See Parisi and O'Hara, supra note 20 at 390 . The availability of an exit option is critical to this conclusion. Competition among the jurisdictions is a necessary condition in the system to limit any inertia towards laws that, for example, flagrantly favor the party from the home state.
} 
lobby for favorable legislation. For example, plaintiffs will generally seek to file claims in jurisdictions where the expected net gain is the largest. The amount of litigation is likely to be positively correlated with the extent to which the jurisdiction's laws favor plaintiffs. Therefore, interest groups that benefit from litigation, such as trial lawyers, would lobby to get such laws passed. To the extent that such interest groups can be organized, the law might be skewed in their favor. ${ }^{28}$

The resulting legislation is "made" law, thesis, in Hayek's terminology, giving rise to a "made" order, taxis. ${ }^{29}$ The laws within this "made" order, due to both imperfect information and the influence of interest groups, have an inherent tendency toward inefficiency. ${ }^{30}$ A large body of literature exists on the role of interest groups in shaping legislation, and is discussed in part below. In this situation, certainty that forum law will always be applied actually increases the incentive to lobby for groups that would benefit from litigation. This leads one to the counter intuitive result that uncertainty about which jurisdiction's law applies would actually reduce

\footnotetext{
${ }^{28}$ See MANCur Olson, The Logic of Collective Action (1969). According to Olson, smaller groups face lower organization costs, and therefore will be able to lobby more successfully for legislation in their favor than large groups. Thus, smaller groups, which are more cohesive, can wield a disproportionate amount of influence on the nature of legislation. This problem of interest groups is an important criticism of the legislative process, a factor that must be taken into account when proposing legislative alternatives to areas currently dominated by the common law.

${ }^{29}$ See Hayek, supra, note 3 at 37, 124-144.

${ }^{30}$ Legislators pass laws with, at best, incomplete knowledge of the both the existing state of the world and the possible consequences of the law they are considering. The law is framed with this base of incomplete knowledge; the impact can only be estimated, not known with certainty. Thus, the legislative body faces the same problem that a central planner does in making decisions to allocate resources for production in an economy. There are simply too many imponderables for a central planner to replicate the efficiency of a market, as the collapse of the centrally planned economies of the former Soviet Union and Eastern Europe suggest. However, the market somehow achieves an astonishing level of efficiency with simple background rules, even when individuals participants have incomplete information. This was a primary theoretical insight of Hayek's work, which has been proved empirically by the experimental economics literature pioneered by Vernon Smith. See Hayek, supra note 3; Vernon L. Smith, Exchange, Economic Theory, and the Hayek Critique, EnCYClOPEDIA OF COGNITIVE SCIENCE; Douglas A. DAVIS and Charles A. Holt, EXPERIMENTAL ECONOMICS (1993).
} 
forum shopping. ${ }^{31}$ This requires applying foreign law as needed through a multilateral approach.

\section{B. Multilateral Approach}

Under the multilateral approach, the judge tries to balance the interests of the sovereigns whose policies could be effectuated, or vitiated, through the litigation. ${ }^{32}$ One way to do this is to have uniform rules that are applied consistently. This is the prevailing consensus in European civil law jurisdictions, which generally favor bright-line tests. ${ }^{33}$ This rules-based approach was shared by the Restatement (First) of Conflicts. Alternatively, a standards-based regime could also take a multilateral approach. Thus, Currie's interest analysis, and much of the Restatement (Second) of Conflicts multi-factor tests are multilateral approaches. ${ }^{34}$ We analyze the benefits and disadvantages of each regime in turn.

The rules of Restatement (First) were based on a vested-rights theory, with territoriality as a guiding principle. ${ }^{35}$ Under these rules based approaches, the court does not consider forum interests in determining which substantive law applies. ${ }^{36}$ As long as the rules are applied consistently, the same substantive law should apply to identical facts, and achieve identical outcomes. Thus, this rules-based system would eliminate forum shopping, by ensuing uniform

\footnotetext{
${ }^{31}$ See Parisi and O'Hara, supra note 20 at 390.

${ }^{32}$ See Cox, supra note 24.

${ }^{33}$ See Parisi and O'Hara, supra note 20 at 389. The system can be traced back to Friedrich Carl von Savigny, who fully articulated a case for rules. Id. at 389-90.

${ }^{34} \mathrm{O}$ 'Hara and Ribstein have criticized this approach as focusing too much on state interests, and not enough on the interests of the individuals. See O'Hara and Ribstein, supra note 8. This criticism is consistent with Hayek's and his criticism of those who consider law to be solely designed through legislation. See Hayek, supra note 3.

${ }^{35}$ See Parisi and O’Hara, supra note 20 at 391; see generally, Brilmayer, supra note 22.

${ }^{36}$ See Cox, supra note 24 at 175.
} 
and predictable results. Thus, under a mirror-image test, a rules-based approach performs extremely well. ${ }^{37}$

The problem, of course, was that the rules, at least under the Restatement (First) were not applied consistently due to the public policy exception and the problem of characterization. Courts often used the public policy exception to avoid applying the clear rule. ${ }^{38}$ Similarly, different results could be obtained, depending on whether the claim was characterized as being based on tort or contract. ${ }^{39}$ The problem was compounded when courts engaged in depecage and applied different states' laws to different legal issues within the same claim, ${ }^{40}$ such that none of states policies were fully effectuated. ${ }^{41}$ The use of escape devices reduced the probability that outcomes would indeed be uniform. The use of escape devices by courts increased the probability that the outcome could vary, depending on the forum where the litigation proceeded, which, in turn, increased the incentive to forum-shop. ${ }^{42}$

\footnotetext{
${ }^{37}$ See Parisi and O'Hara, supra note 20 at 390.

${ }^{38}$ See e.g., Paul v. Nat'l Life, 352 S.E.2d 550 (W. Va. 1986). Two West Virginia residents drove into Indiana, where they were involved in a one-car accident, resulting in their deaths. The estate of the passenger sued the estate of the driver for wrongful death. Indiana had a guest statute which granted immunity to the defendant. The West Virginia trial court applied Indiana law, as being consistent with Restatement (First) rules, that is, the law of the place of the tort applies. On appeal, after critiquing modern approaches to conflicts, and insisting that Restatement (First) was the state's preferred approach, Judge Neely used the public policy exception to reverse the trial court's decision, holding that West Virginia law should apply. The Restatement (First)'s rule of place of injury for tort was circumvented by this decision.

${ }^{39}$ See, e.g., Levy v. Daniel's U-Drive Auto Renting Co. 108 Conn. 333 (1928). The defendant rented a car in Connecticut, and had an accident in Massachusetts. Connecticut imposed vicarious liability on lessor; Massachusetts did not. This case could be characterized as either based in tort or contract. The Connecticut court chose to characterize as a claim based in contract and so avoid the Restatement (First) rule of place of injury for torts.

${ }^{40}$ See O'Hara and Ribstein, supra note 8 at 1192.

${ }^{41}$ See O’Hara and Ribstein supra note 8.

${ }^{42}$ Some empirical work suggests that this problem might not have been as severe as originally thought. See Parisi and O'Hara, supra note 20 for a brief summary.
} 
Standards based approaches, such as Restatement (Second) and Currie's interest analysis, de-emphasize the goals of uniformity and predictability. This is a relativist approach to sovereignty. ${ }^{43}$ There is thus "no reason why every case of the same type [would trigger]. . the same kinds of interests." 44 In these standards based approaches, the court undertakes a process of conflicts analysis. There are no clear a priori rules that emerge. These standards based regimes perform poorly under a mirror-image test, in that it is quite likely that the conflicts analysis will vary, depending on the court undertaking it, and consequently, the outcome could depend heavily on the forum of litigation.

The standards based regimes have been criticized for the lack of clarity and predictability, and the opportunities they provide for forum shopping. But these regimes, in fact, accept the increased probability of forum shopping as a reasonable tradeoff in achieving the objective of furthering state interests. A more cogent criticism focuses on Currie's emphasis on state interests. State interests are reflected in legislation. Unfortunately, as public choice theory makes clear, in a world with interest groups and lobbying, there is no reason to believe that legislation ultimately enacted is socially optimal. ${ }^{45}$ Thus, a focus on state interests puts special interest

\footnotetext{
${ }^{43}$ See Cox supra note 24 at 187.

${ }^{44} I d$.

${ }^{45}$ See Olson, supra note 28; Mueller, supra note 26 . This might be a particularly serious problem when the interest groups are unopposed. Like much public choice theory, we can start from the assumption that a primary goal of legislators is to get re-elected, and one way to do this is to maximize campaign contributions. The groups that can organize can also do so to make contributions, and obtain access to legislators. Therefore, the legislators will tend to push for legislation that favors the special interest group that contributes to their campaign. See e.g., Gene M. Grossman and Elhanan Helpman, Electoral Competition and Special Interest Politics, 63 REV. ECON. STUDIES 265 (1996). Legislation that imposed trade barriers, such as tariffs, is a particularly egregious example that favors one small group, the industry being protected, at the expense of a much larger group, the consumers that pay higher prices. This distortionary effect might be moderated in the presence of opposing interest groups, where swinging too far in favor of one group could result in a backlash from opposing groups against that political party. See Richard Ball, Opposition Backlash and Platform Convergence in a Spatial Model with Campaign Contributions, 98 PUBLIC CHOICE 269 (1999).
} 
groups ahead of individuals. ${ }^{46}$ The focus on legislation is troubling, as it implies a focus on "made order, ${ }^{, 47}$ rather than considering the optimality of spontaneous order, which is essential in a common law system.

\section{Substantive Approach}

Under the substantive law approach, the goal is to eliminate sovereign concerns. ${ }^{48}$ The court is freed from the consideration of any the interests of any particular sovereign, and can choose the best applicable substantive law. ${ }^{49}$ This, in effect, is Leflar's "better law" approach. In theory, this should encourage a "race to the top" for any case.

This approach probably works best in mass litigation situations, such as class action litigation. ${ }^{50}$ Such cases are essentially without boundaries, and a search for the better law might well yield the most efficient, and just, outcome. But it is less likely to be optimal in cases where territorial boundaries matter, such as unintentional torts. This freedom to choose the "best law" is even harder to sustain in cases where parties can make a choice of law ex ante, as in a contract or a market tort, if it meant overruling this choice.

Another fundamental problem with a substantive approach is its emphasis on the "extrasovereign nature of any conflicts fact pattern." ${ }^{51}$ Choosing the best law can be accomplished efficiently only if judges were as well versed in foreign law as they are in their own. This

\footnotetext{
${ }^{46}$ See O'Hara and Ribstein, supra note 8 at 1170.

${ }^{47}$ See Hayek, supra note 3.

${ }^{48}$ See Cox supra note 24.

${ }^{49}$ See Cox supra note 24 at 173-74.

${ }^{50}$ See Cox supra note 24 at $179-80$.

${ }^{51}$ See Cox supra note 24 at 173.
} 
requires considerable investment of human capital in acquiring such knowledge. Given that much of their workload will require application of forum law, judges have little incentive to undertake such investment. And, once judges make substantial investment of human capital in acquiring knowledge of forum law, they are likely be biased in favor of applying forum law. If such a bias exists, the possibility of forum shopping cannot be discounted, as litigants become aware of the bias.

\section{ADVERSE SELECTION AND MORAL HAZARD IN FORUM SHOPPING}

The world is an uncertain place. The possibility of forum shopping arises only in the context of uncertainty. ${ }^{52}$ When there is uncertainty, parties undertake strategic choices in two contexts: choice of the opposing party; and choice of forum. ${ }^{53}$ In the context of litigation, this means:

(i) Defendant chooses plaintiff or

(ii) Plaintiff chooses defendant.

At the second step, once litigation has commenced, a further choice has to be made: that of forum. This choice can be made be either the plaintiff or defendant. Thus, this is a sequential game with the following extensive form:

\footnotetext{
${ }^{52}$ In a world with perfect information, and perfect certainty, agents could foresee all events accurately, and there would be no opportunity to forum shop, because, for example, they could agree on a forum ex ante.

${ }^{53}$ See Moore and Parisi, supra note 8.
} 
Figure 1: Two-sided Adverse Selection Game

\begin{tabular}{l}
\hline : Litigation \\
$\begin{array}{l}\Delta: \text { :endant } \\
\text { Expected payoffs in parentheses }(\Delta, \Pi) \\
\text { Litigation is treated as a zero sum game here. }\end{array}$ \\
\hline$(1,-1)$
\end{tabular}

In the context of litigation, the first step is the choice of parties. The plaintiff can pick the defendant, or the other way around. A third possibility also exists: neither exerts full control over choice of party. For example, in the case of an intentional tort, the defendant picks the plaintiff. An example of where the plaintiff picks the defendant is a variation of an intentional tort: a declaratory judgment action. ${ }^{54}$ Strictly speaking, the "natural" plaintiff is the holder of the patent property right. In a declaratory judgment action, the infringer, the "natural" defendant, becomes the plaintiff. ${ }^{55}$ An example of the third case is a contract claim. A contract is a consensual transaction; neither party exerts unilateral control over choice of the other party.

This is the step where the problem of adverse selection occurs. The party with the control has private information that allows him to choose his opponent. ${ }^{56}$ The choice of participation can

\footnotetext{
${ }^{54}$ See Moore supra note 8; and Moore and Parisi supra note 8.

${ }^{55}$ See Moore supra note 8.

${ }^{56}$ See Akerloff supra note 16, and Stiglitz and Weiss supra note 16, and text.
} 
be strategic, and is the equivalent of adverse selection in the litigation context. ${ }^{57}$ There is twosided adverse selection in the state, as a whole, because the party with the control can be either defendant or plaintiff. ${ }^{58}$ For each case, there is strong likelihood that there is adverse selection on one side.

Once litigation commences, the second step is the selection of the forum in which to pursue the suit. This choice can rest with the plaintiff, the defendant or neither. ${ }^{59}$ If the same substantive law will apply, then there is no room for strategic choice of forum. ${ }^{60}$ The ability to choose the forum will have strategic value only if there is a positive probability that the outcome will be different across different states. A rational party will choose the forum that is most likely to yield a favorable outcome. ${ }^{61}$ This is the problem of moral hazard. ${ }^{62}$

Consider the case where the same party chooses both the opponent and the forum. The party can be either the defendant or the plaintiff. The party who controls both is clearly at a

\footnotetext{
${ }^{57}$ See Moore and Parisi supra note 8.

${ }^{58}$ The discussion here does not include a formal proof, which is outside the scope of the paper. Douglas Gale provided formal proof of equilibrium in markets with two-sided adverse selection, such that separation of the different classes of agents occurs. See Douglas Gale, Signaling in Markets With Two-Sided Adverse Selection, 18 ECON. THEORY 391 (2001). For a presentation of an extensive form game with adverse selection, see John Duggan, An Extensive Form Solution to The Adverse Selection Problem in Principal/Multi-agent Environments, 3 REV. ECON. DESIGN 167 (1998).

${ }^{59}$ See Moore and Parisi, supra note 8, where these alternatives are presented in matrix form.

${ }^{60}$ That is, if all the possible forums use rules to satisfy apply mirror-image tests, there is no strategic advantage that can be gained from a choice of forum. See Parisi and O'Hara, supra note 20; and discussion, supra Part II.B. One example is a rule that the situs determines the applicable law in any claims arising out of real property. This is the rule for both Restatement (First) and Restatement (Second). As long as the situs rule applies, and the property is immovable, the same substantive law will apply regardless of where the suit is brought. In this case, any strategic advantage that can be gained from choice of forum has to come from other sources, such as the applicable statute of limitations. That is the choice of forum is a multi-dimensional issue. See discussion infra Part III. See also Moore, supra note 8.

${ }^{61}$ That is, the party that can choose the forum will choose one that maximized expected net benefits. See O'Hara and Ribstein, supra note 8.

${ }^{62}$ See Shavell supra note 17 and text.
} 
strategic advantage. A good illustration is, as discussed above, the declaratory judgment action. This is one case where the plaintiff can control the choice of defendant and forum. ${ }^{63}$ The potential infringer can choose the patent to infringe upon (that is, the defendant) and the location to conduct the infringing activity (this becomes a possible forum). The potential infringer can choose to locate in a jurisdiction that offers relatively lower levels of protection for patent rights. The result is that it is much harder for the patent holder to protect his property right. To the extent that patent laws are efficient, this opportunity to infringe on the rights created by patents by forum selection is inefficient.

Consider the case where the defendant picks the plaintiff, but the plaintiff picks the forum. The control exerted by the plaintiff at the second stage exerts countervailing pressure on the defendant. The choice of forum is now the plaintiff's - which adds uncertainty to the defendant's calculus. Now the defendant, before choosing the plaintiff, has to factor in the possible choices that the plaintiff could make with respect to forum. As the plaintiff controls the forum, the defendant is unable to determine with certainty that the forum chosen will favor him. In fact, the defendant can reasonably assume that the plaintiff will choose a plaintiff-favoring forum. ${ }^{64}$ This acts as an ex ante deterrent for the defendant from undertaking actions that will result in litigation. In fact, much of conflicts law, in conjunction with venue and transfer statutes, and jurisdiction restrictions, results in this sort of countervailing power, where choices are available.

\footnotetext{
${ }^{63}$ See Moore and Parisi supra note 8.

${ }^{64}$ That is, the choice of forum is ex post, and the plaintiff will choose strategically. See Moore and Parisi supra note 8.
} 
Nonetheless, the various approaches to conflicts law continue to receive criticism, and suggestions for improvement. ${ }^{65}$ Forum shopping, and the associated uncertainty is one concern that repeatedly surfaces in this literature. One commentator has also suggested that conflicts law is at best marginally relevant. ${ }^{66}$ Forum shopping, it will be argued, is part of the common law system that supports a Hayekian law of liberty. ${ }^{67}$ Attempts at grandiose reform, based on academic theories, are likely to fail, for the same reasons that planned economies failed - the problem of information in an uncertain world.

\section{CONFLICTS LAW As SPONTANEOUS ORDER}

Much of the criticism of the various regimes of conflicts law is based on the notion that standards, and varying regimes create uncertainty, which increases transaction costs. The uncertainty affects actions ex ante; agents can either overcompensate or under-compensate to deal with the uncertainty. ${ }^{68}$ Forum shopping also increases litigation costs by adding an issue that needs to be litigated - the choice of forum and law. ${ }^{69}$ It can also trigger a "race to the

\footnotetext{
${ }^{65}$ See authorities cited supra notes 8,9,10 and 13. There are a few defenders of forum shopping. See e.g., Antony L. Ryan, Principles of Forum Selection, 103 W. Va. L. Rev. 167 (complaining that the term forum 'shopping' is derogatory); and Note: Forum Shopping Reconsidered, 103 Harv. L. Rev. 1677 (claiming that such choice is helpful in achieving legitimate goals of the justice system.). See also Robert M. Cover, The Uses of Jurisdictional Redundancy: Interest, Ideology and Innovation, 22 WM. \& MARY L. REV. 639 (1981).

${ }^{66}$ See Sterk supra note 13.

${ }^{67}$ The advantages of ex ante choice of forum are apparent. Ex post forum shopping is more problematic, as we discuss below.

${ }^{68}$ See, e.g., Moore supra note 8 (pointing out that uncertainty about the scope of the patent might result in an effective grant of a broader right to the patent holder, as competitors try to avoid an infringement suit).

${ }^{69}$ If some individuals are statistically more likely to be plaintiffs than defendants, the opportunity for forum shopping may have biased distributional effects with a potential impact on the ex ante incentives of the parties. In contrast, the ex post efficiency implications are independent of the random nature of the status of plaintiff. The plaintiff's advantage will trigger a "race to the courthouse," inducing potential defendants to expedite the filing in
} 
courthouse" as parties file cases strategically. Forum shopping can also result in the overburdening of certain courts, as litigants seek the most favorable forum. ${ }^{70}$ In addition, there is a normative component, centered about the idea that the possibility of forum shopping implies that the law is can be manipulated. Thus, forum shopping undermines the authority of substantive state law. $^{71}$

Of these arguments, the effect of ex ante uncertainty over parties' actions, and the ex post effects in the litigation over the forum are among the most substantial. Decreasing uncertainty is clearly desirable. What is less clear is the best way to do so.

In theory, conflicts rules that always pass the mirror-image test seem optimal. Given uncertainty in so many other aspects of the transaction and litigation, clear rules might not be welfare-maximizing, in the sense that substantive polices effectuated are ones that maximize the welfare of the citizens of the state. The proposals there can be set of clear conflicts rules that always meet the mirror-image tests are victims of the nirvana fallacy. The fact is that even under the rules of the Restatement (First), courts became adept at using escape devices and

order to preempt the opponent's choice of jurisdiction. Once a party establishes jurisdiction, the opponent's claim is generally litigated as a counterclaim or reconventional demand. The "race to the courthouse" may thus have substantial efficiency implications, accelerating the filing process and bringing to trial cases that may not have matured into court claims, had they been left to the choice of the natural plaintiff. Litigating such cases is clearly inefficient. See Parisi and O'Harasupra note 20

${ }^{70}$ See Note, supra note 65 at 1684. Moore, undertakes empirical analysis, and finds that a disproportionately high number of patent claims are filed in certain courts, such as the Eastern District of Virginia ("the Rocket Docket"). But, she also finds very high transfer rates out of this court. Litigants might favor the Eastern District of Virginia due to the speed of resolution and the expertise of the judges in technical patent matters. See Moore supra note 8. But both these grounds seem to quite legitimate reasons to prefer this court. That is, this is legitimate forum selection, which is welfare-enhancing, rather than forum shopping which might be a zero or negative sum game. The transfer rate might suggest that the judges are quite good at weeding out cases that are illegitimate forum shopping.

${ }^{71}$ See Note, supra note 65 at 1684. This importance assigned to uniform outcomes and nonmanipulablity of law is base on version of legal positivism. $I d$. at 1685. The underlying notion is one of the law being immutable. See Moore and Parisi supra note 8. However, as Hayek pointed out, society is continuously evolving, as is the law. Given that the law is not immutable, this uniformity is unsustainable inter-temporally. See Hayek supra note 3. 
characterization to avoid the outcomes that would have followed if the rules had been scrupulously followed. ${ }^{72}$

Fundamentally, the idea of rigidly followed conflicts rules, as a legal issue wholly separate from the substantive claim, is alien to the working of the common law system. As Stewart Sterk points out,

common law judges do not decide cases deductively, starting with major premises and then applying those premises to the facts at hand. Instead the start with the facts before them, form a tentative judgment about which party deserves to win, and then use precedent and other sources of authority as a background against which to check, or rethink, their conclusions. ${ }^{73}$

He then cites the late Charles D. Brietel, the former chief judge of the New York Court of Appeal, as explaining the process that judges followed. According to Breitel, judges first asked themselves which party deserved to win. Only after they had determined where justice lay in the individual case did the judge ask the next question: "What harm to the jurisprudence will result if I do justice in the individual case?"74

Even though Sterk uses this to support his thesis about the "marginal significance" of conflicts theory, the process he describes is very much like the one Hayek describes as one that results in spontaneous order. ${ }^{75}$ The judge weighs expectations in view of existing rules, in making his determination of which expectations to fulfill. ${ }^{76}$ That is, the judge makes a decision about which party deserves to win, and tries to estimate how the outcome will diverge from

\footnotetext{
${ }^{72}$ See e.g., Friedrich K. Juenger, Forum Shopping, Domestic and International, 63 TUL. L. REV. 553 (1989). See also, discussion supra Part I.B.

${ }^{73}$ Sterk supra note 13 at $994-995$.

${ }^{74}$ Sterk supra note 13 at 995 . Sterk also quotes Cardozo, "the common law does not work from pre-established truths of universal and inflexible validity to conclusions derived from them deductively. Its method is inductive, and it draws its generalizations from particulars." Id. quoting BENJAMIN N. CARDOZO, THE NATURE OF THE JUDICIAL PROCESS 22-23 (1921).

${ }^{75}$ See Hayek supra note 3 at 102.

${ }^{76}$ See Hayek supra note 3.
} 
existing rules. The judge, as much as any other agent in society, has information that is fragmented. The judge will not always be correct, but, over time, just rules, which permit the perpetuation of a social order will survive, and evolve. ${ }^{77}$ This is the essential process for the evolution of spontaneous order. ${ }^{78}$

If Hayek is right, the common law should be a continuously evolving spontaneous order. In the section below, we examine the evolution of conflicts law in three broad categories contracts, torts and real property - from Restatement (First) to Restatement (Second) for evidnce of such an evolution. It is not only the move from rules to standards, but also the concurrent evolution of personal jurisdiction principles that is important in any analysis of conflicts law from a Hayekian perspective.

\section{A. Contracts}

The division of power over party choice and forum choice differs across different sorts of claims. Thus, for example, most contracts are entered into voluntarily. In a contract, both parties have power over the choice to participate. It is reasonable to assume that the choice of law and

\footnotetext{
${ }^{77} I d$.

${ }^{78}$ Common law shares this characteristic of evolution towards efficiency with free markets, even when much of the information is not merely fragmented, but also inarticulated. Hayek was among the earliest to recognize this, supra note 1. See also Carlo Zappia, Private Information, Contractual Arrangements and Hayek's Knowledge Problem, manuscript, DEPARTMENT OF ECONOMICS, UnIVERSITY OF SIENA (1995). Evidence from experimental economics has demonstrated convincingly that markets can achieve very high levels of efficiency even when information is fragmented in this Hayekian sense. If markets can do this, there is no a priori reason to assume that the common law will fail to achieve a similar success. See e.g., Vernon L. Smith, Microeconomic Systems as an Experimental Science, 72 AM. ECON. REV. 923 (1982) (proving in experiments that even when agents have private information about costs and utility, the market can achieve an equilibrium that is extremely close to the competitive one); Vernon L. Smith, Exchange, Economic Theory, and the Hayek Critique, ENCYClOPEDIA OF COGNITIVE SCIENCE. See generally, Douglas A. DAVIS and Charles A. Holt, EXPERIMENTAL ECONOMICS (1993).
} 
forum in the contract reflect the ex ante preferences of the parties, and are welfare maximizing. ${ }^{79}$ It seems intuitively reasonable enforce such choices. ${ }^{80}$

However, the Restatement (First) did not generally permit the enforcement of a choice of law clause made by the contracting parties. ${ }^{81}$ Such contract clauses were disfavored, as being "private law." According to Restatement (First), the law of the place of contract applied. ${ }^{82}$ Restatement (Second) explicitly provided for honoring the voluntary choice of law by contracting parties. ${ }^{83}$ In cases where the parties failed to make such a choice, the Restatement

\footnotetext{
${ }^{79}$ This choice is also likely to be the efficient one, especially if the contract is not one of adhesion. See O'Hara and Ribstein, supra note 8.

${ }^{80}$ On the other hand, the relationships entered into as a result of torts are at least partially, and often wholly, involuntary in nature. If the defendant chose the plaintiff, it is reasonable to leave the choice of forum to the plaintiff under the framework of adverse selection and moral hazard discussed supra. Conflicts law for torts is discussed infra Part III.B.
}

${ }^{81}$ See generally, Brilmayer, supra note 22. According RESTATEMENT (FIRST) OF THE LAW OF CONFLICTS OF LAW (herinafter RESTATEMENT (FIRST) OF CONFLICTS), § 7, comment on clause (b),

c. Choice of Law. When an action is brought upon a contract made in another state, the court at the forum must decide, by its own rules of Conflicts of Laws, by the law of what state the situation is to be controlled. If it decides that that law of the second state is to be applied, it must thereupon decide whether it is the entire law of the other states, including its Conflicts of Laws rules, or only its rules pertaining to the law of contracts when no question of foreign law is involved. Under the rule stated in this Section, the court at the forum applies only the contract law of the other state.

Under $\S \S 311$ et seq., the law of the place of contracting applied to all contracts. There is no provision for a choice of a third state law by the parties.

${ }^{82}$ RESTATEMENT (FIRST) OF CONFLICTS $\S \S 311$ et seq.

${ }^{83}$ Restatement (SECOND) OF THE LAW OF CONFLiCTS OF LAW (hereinafter RESTATEMENT (SECOND) OF CONFLICTS).

\section{$\S 187$, Law of the State Chosen by the Parties}

(1) The law of state chosen by the parties to govern their contractual rights and duties will be applied if the particular issue is one which the parties could have resolved by an explicit provision in their agreement directed to that issue.

(2)The law of the state chosen by the parties to govern their contractual rights and duties will be applied, even if the particular issue is one the parties could not have resolved by an explicit provision in their agreement directed to that issue, unless either,

(a) the chosen state has no substantial relationship to the parties or the transaction and there is no reasonable basis for the parties' choice or

(b) application of the law of the chosen state would be contrary to a fundamental policy of a state which has a materially greater interest than the chosen state .... 
(Second) set up a multi-factor test to determine the state with the most significant relationship with the case, which would then be the law applied. ${ }^{84}$

The modern rule is for courts to honor choice of law and choice of forum clauses almost always. ${ }^{85}$ The disfavored treatment of choice of law clauses is one part of Restatement (First) that has been discarded even in states that otherwise still follow Restatement (First) ruled for conflicts. Restatement (Second) explicitly allows for the parties to choose the applicable law.

It seems not only efficient, but also just to recognize the parties ex ante choice of law. An ex ante choice of law, as a contract clause, eliminates the adverse selection and moral hazard problems discussed above. The bargaining is done before the contract is signed; the final provisions reflect an outcome that is welfare enhancing for both parties. If this were not the case, the contract would not be effectuated. There is no room left for strategic choice of forum, once the choice has been made in the contract provisions. This explicit choice also eliminates uncertainty, and an issue for litigation. Honoring a contractual choice of law also enhances judicial economy. It is not surprising, viewed from a Hayekian perspective, that the Restatement

(3) In the absence of a contrary indication of intention, the reference is the local law of the state of the chosen law.

${ }^{84}$ Restatement (SECOND) OF CONFLICTS, § 188, Law Governing in Absence of Effective Choice by The Parties (1) The rights and duties of the parties with respect to an issue in contract are determined by the local law of the state which, with respect to that issue, has the most significant relationship to the transaction and the parties under the principles stated in $\S 6 . \ldots$

(Section 6 sets out the factors to be taken into consideration in choice of law questions.).

${ }^{85}$ The U.S. Supreme Court has upheld a choice of law even when it was the state of neither party. See The Bremen v. Zapata Off-shore Co., 407 U.S. 1 (1972) (upholding choice of law of a third country). Sometimes choice of forum in contract that is effectively one of adhesion, has been upheld. See, e.g., Carnival Cruise Lines, Inc. v. Shute, (499 U.S. 585 (1991) (upholding the choice of forum clause in the fine print in a ticket, where the term was not bargained for). 
(First) rule disfavoring contractual choice of law clauses has effectively become obsolete, and has been replaced by a rule that is more efficient. ${ }^{86}$

This conclusion holds for cases where there is an explicit choice of law in the contract. In the absence of such a explicit choice of law clause, Restatement (Second) applies a multi-factor test. ${ }^{87}$ As with any standards based approach, this leaves room for ambiguity. The assessment of which state has the most significant relationship is dependant on a number of factors, many of which will be evaluated subjectively by the judge. That is, there is some room for strategic forum shopping. But the Restatement (First) was not entirely objective either. The court could use escape devices, such as characterization, public policy and renvoi, to evade the outcome dictated by the rule. ${ }^{88}$ The frequency of use of escape devices could vary across courts, and a plaintiff could engage in strategic forum shopping even in a rules-based regime. Thus, the Restatement (Second) need not necessarily increase uncertainty in a contract claim. Further, if it is true that the modern approaches tend to favor the forum state, ${ }^{89}$ this is something that the parties can take into account when drafting the contract, and during performance, even in the absence of an explicit choice of law clause. Lastly, if conflicts law is an example of spontaneous order, this rule will eventually become part of the possibly unarticulated rules that make up the social order, further diminishing socially undesirable forum shopping.

\footnotetext{
${ }^{86}$ For a comprehensive analysis of the efficiency considerations in favor of enforcing contractual choice of law, see O'Hara and Ribstein, supra note 8.

${ }^{87}$ RESTATEMENT SECOND OF CONFLICTS, $§ \S 188,6$.

${ }^{88}$ See generally, Brilmayer, supra note 22.

${ }^{89}$ Certain empirical evidence suggests that the modern approaches, including Restatement (Second), are more forum-oriented that Restatement (First). See e.g. P. Bouchers, The Choice of Law Revolution: An Empirical Study, 49 WASH. \& LEE. L. REV. 357 (1992); M. Solomine, An Economic and Empirical Analysis of Choice of Law, 24 GEORGIA L. REV. 49 (1989). But the most rigorous econometric study extant finds that while the modern approach states use forum law more often than states using the Restatement (First), there was very little difference at the margin between the two groups when it came to recovery favoring choice of law rulings. See Parisi and O'Hara, supra note 20, citing S.Thiel, Choice of Law and the Home Court Advantage. Ultimately what the parties care about is recovery - and there seems to be little strategic advantage to gained through forum shopping.
} 


\section{B. Torts}

Claims based on tort law are probably the most justified target for concerns about strategic, illegitimate forum shopping. There is one critical difference between tort-based relationships and contract-based relationships. Contractual relationships are essentially consensual in nature. The relationship between the tort-feasor and the victim is essentially nonconsensual. In the case of an intentional tort, the tort-feasor chooses the victim; that is, the defendant chooses the plaintiff. In an unintentional tort, the tort-feasor does not choose a specific victim, but acts in such a way as increase the risk of some class of persons becoming victims. ${ }^{90}$ Thus, in a tort claim, the strategic choice of participation lies with the defendant. ${ }^{91}$ Allowing the choice of forum to rest with the plaintiff is a way of countervailing this adverse selection problem.

The Restatement (First) rule was the law of the place of the wrong applied. The place of the wrong was defined as the place where "the last event necessary to make the actor liable for an alleged wrong takes place. . ." 92 The problem with such a rule in the case of intentional torts is quite obvious. The defendant can control the choice of law by deciding the forum in which to commit the last necessary act. For example, an actor seeking to infringe copyright, or undertake defamation, can choose his victim, and choose the state in which to under the act. The defendant controls both the strategic participation choice and the strategic forum choice. This result of the

\footnotetext{
${ }^{90}$ The classic unintentional tort is a traffic accident. The tort-feasor does not choose to run down a specific victim, but, by driving recklessly, endangers other people on the road with him; that is, the reckless driver increases the risk of one of the other drivers becoming a victim, and suffering loss.

${ }^{91}$ See discussion supra Part II; see also, Moore and Parisi, supra note 8.

${ }^{92}$ RESTATEMENT (FIRST) OF CONFLICTS $§ 377$. This is a lex locus delecti rule.
} 
rule is likely to be very unfavorable to the plaintiff - the party that has to bear the loss caused by the action of the defendant.

The rule of the last necessary act is not quite so egregious in the case of unintentional torts. However, the rule can result in outcomes that violate expectations that would otherwise be justified. Consider the case of Alabama Great South. R.R. v. Carroll. ${ }^{93}$ The plaintiff employee was a resident of Alabama, as was defendant employer. The negligent conduct took place in Alabama, but the actual injury occurred in Mississippi. The court applied Mississippi law, which denied the plaintiff certain damages he would have recovered under Alabama law. In this case, the parties' could have reasonably justified expectations that their common domicile would govern the loss distribution rules. However, the lex locus delecti rule of Restatement (First) would not permit this separation of conduct regulating rules from loss distribution rules.

It is not surprising that courts used escape devices so often in torts cases under the Restatement (First) regime. The court invoked the public policy exception in Paul v. Nat'l Life, ${ }^{94}$ to allow the citizen plaintiff to recover damages that would have been barred under the lex locus delecti rule. Tort law was the first area where conflicts law evolved away from such a rigid rule. The often criticized cases based on grouping of contacts, including Babcock v. Johnson, ${ }^{95}$ Neumeier v. Kuehner, ${ }^{96}$ and Schultz v. Boy Scouts of America, Inc, all demonstrated an effort by

\footnotetext{
${ }^{93} 97$ Ala. 126 (1892).

${ }^{94} 352$ S.E.2d 550 (W. Va. 1986). See text supra note 38.

${ }^{95} 191$ N.E.2d 279 (N.Y. 1963). Plaintiff and defendant were New York residents. The accident occurred in Ontario, which had a guest statute barring recovery. New York law permitted recovery. The court applied New York law, on the basis that New York was the center of gravity.

${ }^{96} 286$ N.E. 2d 454 (1972). Plaintiff was from Ontario; defendant from New York. The accident took place in Ontario. The court applied Ontario law, as being fair to the plaintiff. The court is concerned about the plaintiff's expectations, as the party who suffered the loss. This is consistent with Sterk's characterization of the common law process, and Hayek's concept of the process of judge-made law. See Sterk supra note 13 and Hayek supra note 3.
} 
the courts to consider party expectations. ${ }^{97}$ The first two were unintentional tort cases; the last was an intentional tort. The court effectively distinguished between conduct regulating rules and loss regulating rules in attempting to achieve a just outcome. The Restatement (Second) took this process further when it set up a multi-factor test to determine which state had the most significant relationship with the claim; the law of this state would be the one that applied. ${ }^{98}$

This test has been justly criticized as being vague and increasing uncertainty in tort cases. But it is not clear that this uncertainty is any more than that created by the use of escape devices under Restatement (First). Further, the uncertainty inherent in the multifactor test has the effect of reducing the adverse selection- moral hazard problem in intentional torts, precisely because it can incorporate possible strategic problems into the analysis. The Restatement (Second) test looks at factors beyond the lex locus delecti, including the domicile of both parties, and the nature of the relationship between the two. ${ }^{99}$ Any consideration of the plaintiff's domicile immediately reduces the strategic advantage in forum selection held by the defendant in an intentional tort claim.

O'Hara and Ribstein have advocated a place of injury rule for non-market torts, and a place of sale rule for product liability cases, where there is no explicit choice of law clause. ${ }^{100}$ They advocate enforcing choice of law clauses where they exist for market-based torts, such as

\footnotetext{
${ }^{97} 480$ N.E.2d 679 (1985). Plaintiff and defendant were New Jersey residents; the tortious conduct took place in New York. The New York court chose to apply New Jersey law on a grouping of contacts analysis. As the issue was conduct regulating rules, applying New Jersey law best fulfils expectations of the parties. Note that is was an intentional tort.

${ }^{98}$ RESTATEMENT (SECOND) OF CONFLICTS $§ \S 145,6$.

${ }^{99}$ RESTATEMENT (SECOND) OF CONFLICTS $§ § 145$.

${ }^{100}$ See O'Hara and Ribstein, supra note 8.
} 
product liability. They argument is based on efficiency considerations, and would certainly reduce ex post strategic forum shopping.

A choice of law clause creates ex ante certainty and eliminates ex post strategic forum shopping. Supreme Court jurisprudence suggests that such a rule is either already in place, or in the process of evolution. In Carnival Cruise Lines, Inc. v. Shute, ${ }^{101}$ the Court upheld the choice of forum clause listed in a cruise ticket, even though the term had not been bargained for. To the extent that the other suggestions are consistent with the common law approach, they should emerge in due time.

\section{Real Property}

Real property is an interesting case, because it is one area where there is still a clear rule in conflicts. Claims based on real property include those of land use, title, ownership interest, testamentary disposition or intestate succession. ${ }^{102}$ The law of the situs, that is, the law of state where the land is located, applies. This was the rule of Restatement (First); ${ }^{103}$ Restatement (Second) effectively retained this rule. ${ }^{104}$ Advocates of efficiency recommend retaining this rule. ${ }^{105}$ Even though Baxter criticized this rule, ${ }^{106}$ there has been remarkably little controversy about the situs rule for real property.

\footnotetext{
101499 U.S. 585 (1991).

${ }^{102}$ See O'Hara and Ribstein supra note 8 at 1219. See generally, Brilmayer, supra note 22.

${ }^{103}$ RESTATEMENT (FIRST) OF CONFLICTS, $\$ \$ 211-251$.

${ }^{104}$ RESTATEMENT (SECOND) OF CONFLICTS, $§ 189$.

105 See O'Hara and Ribstein, supra note 8 at $1219-1221$.

${ }^{106}$ According to Baxter, the relevant relationship is that between sovereigns and people, not sovereigns and property. See William F. Baxter, Choice of Law and The Federal System, 16 STAN. L. REV. 1 (1963) (arguing that the objective of choice of law should be to maximize effectuation of states' interests).
} 
This rule can be justified due to the unique feature of real property - its immovability. Any ruling affecting real property will inevitably impact the situs state. The situs state is most likely to have a regulatory advantage in determining the use of real property, such land use, zoning and nuisance laws. That is, real property can result in externalities; the situs state is in the best position to determine the nature of these externalities, and regulatory action needed to correct negative externalities. ${ }^{107}$ In the case of real property, where there are externalities, the participation choice rests with the land user; to the extent there are negative externalities, those affected by such externalities have no participation choice. Thus, the land user has advantage in the adverse selection problem.

Enforcing the law of the situs state offsets such a strategic advantage. A clear situs rule for real property also has other benefits. It eliminates uncertainty in two significant ways. First, there is a clear ex ante rule about which law applies. This eliminates the possibility of strategic forum shopping. The law of the situs rule also eliminates one source of uncertainty in the clarity of title. This clarifies property rights, and makes transfers easier. Part of the function of the social order is to clarify property rights so as to permit exchange. ${ }^{108}$ From a Hayekian perspective, it is not surprising that the situs rule for real property has survived.

\section{Personal Jurisdiction}

The evolution of conflicts law cannot be discussed sensibly without an examination of the evolution of the doctrine of personal jurisdiction. There are two main concerns in limiting

\footnotetext{
${ }^{107}$ See O'Hara and Ribstein, supra note 8 at 1220.

${ }^{108}$ See Hayek supra note 3.
} 
choice of forums and law. First, the law is concerned about fairness to parties. ${ }^{109}$ Second, the law is concerned about comity, so as to reduce friction between the various jurisdictions. In the U.S. context, this second concern falls with the ambit of the Full Faith and Credit clause. ${ }^{110}$ In the international context, concerns about comity arise from the need to cooperate, so as to maintain a functional system of international law, comprised of sovereign states. ${ }^{111}$

Personal jurisdiction can act as a counterweight to the forum-shopping problem. The evolution of conflicts law away from the rules of Restatement (First) has increased the availability of forums available to parties. Personal jurisdiction doctrine has evolved so as to limit the possibility of strategic forum shopping by the plaintiff. Erie R.R. v. Tompkins ${ }^{112}$ effectively eliminated the opportunity to forum shop between federal and state courts. The move from the tag jurisdiction held constitutional in Pennoyer $v$. Neff ${ }^{13}$ to the minimum contacts test of International Shoe Co. v. Washington ${ }^{114}$ to the "purposeful availment" test of McGee v.Int'l Life Ins. Co ${ }^{115}$ has considerably restricted a jurisdiction's assertion of personal jurisdiction on any party. That is, when the plaintiff has the opportunity to choose the forum strategically, the personal jurisdiction requirements limit the number of forums the plaintiff can choose. The

\footnotetext{
${ }^{109}$ This is a fundamental concern for any system of rule of law. In the U.S., the Constitutional foundation is found in the Due Process clause. See U.S. Const. AmENDS. V and XIV $§ 1$.

${ }^{110}$ U.S. CONST. Art. IV. $§ 1$.

111 That is, the sovereigns follow the principle of reciprocity.

112304 U.S. 64 (1938).

11395 U.S. 714 (1877) (holding that physical presence in the state is sufficient for assertion of in personam jurisdiction).

114326 U.S. 310 (1945) (setting up the requirement for "minimum contacts" adequate to establish "fair play and substantial justice" for the assertion of personal jurisdiction that was constitutionally proper).

115355 U.S. 220 (1957) (creating the three part test for personal jurisdiction: state interest, forum not unduly inconvenient and purposeful availment of the forum).
} 
plaintiff's adverse selection/ moral hazard problem is thus constrained by the need to find a forum that can assert personal jurisdiction. Obviously the one forum the defendant can always be sued is his own domicile. But this is likely to not be a favorable forum for the plaintiff, as the defendant will choose a domicile that is favorable to him, if such choice is at all possible. ${ }^{116}$

The fact that personal jurisdiction limits have evolved is a way that acts as a counterweight to possible problems in the relaxation of choice of forum suggests that the process is in fact the evolution of spontaneous order.

\section{FORUM SELECTION VERSUS FORUM SHOPPING}

Forum selection, or shopping, is a multi-dimensional activity. ${ }^{117}$ Forum selection is an integral part of the legal process in a world with multiple jurisdictions. The choice of forum may give the party some control over both procedural and substantive law. ${ }^{118}$ Generally, the forum applies its own procedural rules to determine what substantive law to apply. ${ }^{119}$

Probably the most egregious forum shopping has been due to statutes of limitations. A statute of limitations is considered to be a procedural rule; so the choice of forum can determine which jurisdiction's statute is to be applied. Variation in the statute of limitations can mean that a suit can be heard in one jurisdiction while it is dismissed in another. That a diametrically opposed outcome possible simply due to a choice of forum is an uncomfortable reminder of the

\footnotetext{
${ }^{116}$ Under very limited circumstances, it might be possible for a defendant to choose a domicile as a way to improve his or her strategic position in case of litigation. Thus, for example, any time domicile may acquire relevance as a primary or secondary connecting factor in the establishment of jurisdiction or applicable law, the strategic choice of a domicile in a pro-defendant jurisdiction may give an advantage to potential defendants in litigation.

${ }^{117}$ See Moore supra note 8; Note supra note 65.

${ }^{118}$ See Note supra note 65 .

${ }^{119}$ This is the case when the court declines renvoi. See Brilmayer, supra note 22.
} 
vast gulf between the ideal of an immutable law and the reality that prevails in a world with uncertainty and fragmented knowledge. Unfortunately, there is no simple or fair way to make this problem disappear. By their nature, a statute of limitations is arbitrary - the legislature picks some length of time after which a claim expires. There are good reasons to have such a statute, including judicial economy and repose for the potential defendant. Forum shopping based on statutes of limitations can possible be limited by borrowing statutes, but cannot be eliminated as long as different states pursue different policies. States can have different durations for such statutes for sound policy reasons, depending on their individual interests. It might be that the cost of eliminating this source of forum shopping might exceed the benefits.

Other reasons for choosing a particular forum might be somewhat less problematic, when the primary reason for choice of forum is something other than increasing the probability of a favorable outcome. ${ }^{120}$ For example, the parties may choose a forum because of the speed of adjudication. ${ }^{121}$ A rapid resolution of the dispute is desirable, as it limits the deadweight costs associated with litigation. Parties may prefer a certain forum because of the expertise of the judges in a specialized area, such as Delaware courts for corporation law. Again, this seems to be forum selection that is efficiency enhancing rather than a zero-sum or negative sum game of forum shopping.

A system that permits alternative forum can also perform a useful function in increasing competition among the states. ${ }^{122}$ As long as exit is possible, states will be less likely to skew

\footnotetext{
${ }^{120}$ That is, when the party choosing the forum is not merely doing so because, for example, that forum will impose lower penalties, as was the case of the second hypothetical discussed at the beginning of the article.

${ }^{121}$ See Moore, supra note 8 (postulating that its reputation for speedy resolution may be one reason why so many patent cases are filed in the Eastern District of Virginia).

${ }^{122}$ See Larry E. Ribstein and Bruce Kobayashi, A Recipe For Cookies (manuscript) (advocating state regulation of privacy on the Internet, based on the idea that competition will result in a race to the top).
} 
laws in favor of a particular class. For example, to the extent that laws do become plaintifffavoring, as in the United States, which has acquired a reputation for having juries that tent to had out large damage awards in tort suits, ${ }^{123}$ there are two limiting factors: the transfer statutes that allow the defendants to seek a transfer of the case to another court, usually from state to federal; ${ }^{124}$ and the personal jurisdiction doctrine. Further, the U.S. Supreme Court has shown itself inhospitable towards alien claims, and has not hesitated to use the forum non conveniens doctrine, ${ }^{125}$ giving little deference to plaintiff's choice of forum, when the forum chosen is a foreign one. The problem with the use of the forum non conveniens doctrine is, of course, that the tort defendant can use this strategically, when the victim is an alien, and the defendant is a U.S. entity. ${ }^{126}$

However, as Hayek said, not every expectation can be satisfied every time. Imperfect, fragmented knowledge, and an evolving order make it impossible to achieve a perfect result every single time. What is both achievable and worthwhile is to have a system where rules evolve, and are tested over time. The inadequate rules get discarded, and the rules that promote liberty are perpetuated. In a continuously evolving society, the ideal of an immutable law with immutable rules is a chimera.

\footnotetext{
${ }^{123}$ See Juenger, supra note 72 (discussing international forum shopping and the reputation of the U.S. as "tort haven").

${ }^{124}$ One such case was World-wide Volkswagen v. Woodson,444 U.S 286 (1980). The defendant's counsel in this products liability suit resisted plaintiffs' efforts to keep the case in state court, where the jury was far more likely to be sympathetic to the plaintiffs. The New York plaintiffs tried to destroy diversity by joining a New York; this tactic failed when the Supreme Court ruled that Oklahoma lacked jurisdiction over the New York defendants. See Juenger supra note 72 .

${ }^{125}$ See Piper Aircraft Co. v. Reyno, 454 U.S.235 (1981).

${ }^{126}$ Juenger uses the example of the chemical disaster in Bhopal, India. Union Carbide managed to get the case moved to Indian courts, even when the Indian government was arguing that its courts were not equipped to deal with the case, and the litigation should proceed in the U.S. See Juenger supra note 72.
} 
Conflicts law is best viewed as a continuously evolving spontaneous order. It is only the fragmented nature of our knowledge that makes it appear that there is no order. Forum shopping, or alternatively, forum selection is part of this order. As such, forum shopping is not going to disappear at any point in the foreseeable future. In fact, as long as there are overlapping jurisdictions and multiple legal regimes, forum shopping (or selection) cannot be eliminated. Nor is it obvious that eliminating forum shopping is unambiguously welfare enhancing. 